\title{
Hepatoprotective activity of Phyllanthus niruri Linn. endophytes
}

\author{
Radhika S. Kodoli', Sunil T. Galatage ${ }^{1 *} \mathbb{D}$, Suresh G. Killedar', Sachin A. Pishwikar', Prasanna V. Habbu² and \\ Durgacharan A. Bhagwat ${ }^{3}$
}

\begin{abstract}
Background: The liver is the vital organ which plays a major role in metabolism with numerous functions in the human beings such as protein synthesis, hormone production, and detoxification. Present research work is focused on hepatoprotective potential of chloroform (PNFC) and ethyl acetate (PNFEA) endophytic fractions from Phyllanthus niruri Linn. against $\mathrm{CCl}_{4}$-induced hepatotoxicity in albino Wistar rats. To test our hypothesis, both endophytic fungal fractions were tested for vitro antioxidant and in vivo hepatoprotective activity. Serum biochemical parameters like SGOT, SGOT, SALP, cholesterol, bilirubin, and protein were estimated to assess hepatoprotective activity.

Results: Group of rats treated with $\mathrm{CCl}_{4}$ possess marked hepatic damage and oxidative stress which indicates that cellular leakage and loss of functional integrity of cell membrane in liver. PNFC and PNFEA fractions of endophyte from Phyllanthus niruri Linn. stem have significantly reduced the elevated levels of biomarkers like SGPT, SGOT, SALP, bilirubin, cholesterol, and total protein in $\mathrm{CCl}_{4}$-induced hepatotoxicity in rats. The results obtained confirm hepatoprotective activity of endophytic fractions (PNFC and PNFEA) mediated through the stabilization of plasma membrane, repair of hepatic tissue damage, return of biochemical marker levels to normal, and regeneration of hepatocytes. Histopathological observations revealed improvement in the liver architecture after the treatment of secondary metabolites of endophytic fractions against $\mathrm{CCl}_{4}$-induced liver damage. Both fungal endophytes PNFC and PNFEA showed DPPH scavenging activity with $I C_{50}$ of $97.79 \mu \mathrm{g} / \mathrm{ml}$ and $108.40 \mu \mathrm{g} / \mathrm{ml}$, respectively, and possess antioxidant potential. Presence of flavonoids in the both fractions of endophytes may be a possible reason for its antioxidant potential and identified as Eurotium amstelodami strain.
\end{abstract}

Conclusion: Both fungal endophytes PNFC and PNFEA possess hepatoprotective potential due to the presence of secondary metabolites of fungi, i.e., Eurotiumam stelodami strain which support the claim endophytes and act as a potent biomedicine for treatment of various chronic diseases.

Keywords: Phyllan, Endophytes, Hepatoprotective, Antioxidant, Microbes

\section{Background}

Worldwide, hepatic diseases are the leading cause of death with liver cirrhosis injury [1]. The liver mainly controls vital physiological processes in human beings such as carbohydrate metabolism and storage, fat metabolism, synthesis of bile acid, and detoxification of various drugs in our body [2]. Hazardous chemicals and excess

\footnotetext{
* Correspondence: gsunil201288@gmail.com

'Sant Gajanan Maharaj College of Pharmacy Mahagaon, 416502,

Tal-Gadhinglaj, Dist-Kolhapur, Maharashtra, India

Full list of author information is available at the end of the article
}

consumption of alcohol are mainly responsible for liver diseases. Commonly included infections are fatty liver cirrhosis cancer, and various chemicals like tert-butyl hydroperoxide, galactosamine, paracetamol, $\mathrm{CCl}_{4}$, acetaminophen, and alcohol, causing potential injury to the liver cells leading to progressive dysfunction. Due to toxic nature of lipid peroxidation (LPO) which is prominent causes liver diseases due to its toxicity $[3,4]$. The Phyllanthus niruri Linn. has great potential to treat various diseases such as hepatitis, stomach ache, gonorrhea, asthma, urolithic disease, fever, malaria, vaginitis to 
tuberculosis, antiradicals and DNA cleavage protectors $[5,6]$. Endophyte was first coined by De Bary and has become deeply embedded in the literature ever since. Nowadays endophytes defined as microbes which colonize alive internal parts of plant without any hazardous effects over it [7]. Endophytes are novel competent herbal medicine with bioactive natural constituent occupied from endophytes [8]. The aim of this present research work is to determine hepatoprotective activity of chloroform (PNFC) and ethyl acetate (PNFEA) endophytic fractions from Phyllanthus niruri Linn. stem against $\mathrm{CCl}_{4}$-induced hepatotoxicity.

\section{Methods}

\section{Isolation of endophytes}

The whole plant was cleaned to remove soil with help of running water and then dried. With the help of $4 \%$ sodium hypochlorite for $5 \mathrm{~min}$, 70\% ethanol for $1 \mathrm{~min}$, and sterile distilled water for 1 min $2-3$ times the plant was sterilized. The surface sterilized plant segment were placed on petri dish containing potato dextrose agar supplemented with streptomycin $(100 \mu \mathrm{g} / \mathrm{ml})$ to inhibit bacterial growth and incubated at $23-25{ }^{\circ} \mathrm{C}$. After 7 to 14 days of incubation fungi isolated were purified. Colony morphology was mainly determined by culture purity [9-11].

\section{Extraction and fermentation}

Isolates endophytic fungi were grown on potato dextrose broth plates at $23-25{ }^{\circ} \mathrm{C}$ for $7-14$ days which are inoculated and fermented separately in potato dextrose broth. After 21 days of incubation at $23-25{ }^{\circ} \mathrm{C}$ each fungal culture is filtered and homogenized at $4000 \mathrm{rpm}$ to separate the mycelia from broth. Fractions showing potential in vitro activity were further used for in vivo study [12].

\section{In vitro steady-state free radical scavenging studies Reaction with DPPH radical}

Equal volume of $100 \mu \mathrm{M}$ DPPH in methanol was added to different concentration of fractions $(20-200 \mu \mathrm{g} / \mathrm{ml})$ in methanol and for $20 \mathrm{~min}$ placed in dark after proper mixing. The absorbance at $517 \mathrm{~nm}$ was measured using ascorbic acid (ASC) as a standard. Different concentrations $(1-5 \mu \mathrm{g} / \mathrm{ml})$ of ASC were homogeneously mixed with equal volumes of DPPH. Plotting the percentage of $\mathrm{DPPH}$ scavenging against ASC concentration gave the standard cure [13].

\section{Reducing power assay}

The reaction mixture contained $1.0 \mathrm{~mL}$ of different concentrations of extracts $(2-10 \mathrm{mg} / \mathrm{mL}), 2.5 \mathrm{~mL}$ of $1 \%$ potassium ferricyanide, and $2.5 \mathrm{~mL}$ of $0.2 \mathrm{~mol} / \mathrm{L}$ sodium phosphate buffer. The mixture was incubated at $50{ }^{\circ} \mathrm{C}$ for $30 \mathrm{~min}$ and the reaction was terminated by the addition of $2.5 \mathrm{~mL}$ of $10 \%$ trichloroacetic acid, followed by centrifugation at $3000 \mathrm{rpm}$ for $10 \mathrm{~min}$. $2.5 \mathrm{~mL}$ of the supernatant was uniformly mixed with $2.5 \mathrm{~mL}$ of deionized water and $0.5 \mathrm{~mL}$ of $0.1 \% \mathrm{FeCl}_{3}$. At $700 \mathrm{~nm}$ absorbance was measured against blank. Increase in absorbance indicates increased reducing power of the sample [14].

\section{Reaction with hydroxyl radical}

$\mathrm{OH}$ scavenging activity of fraction was determined by degradation of deoxy-D-ribose method. To the reaction mixture having ascorbic acid $(0.1 \mathrm{mM})$ and hydrogen peroxide $(2 \mathrm{mM})$ in different concentrations of the extract/fractions in a volume of $0.3 \mathrm{ml}$ were added to get volume of $3.0 \mathrm{ml}$. After $30 \mathrm{~min}$ of incubation, $1.0 \mathrm{ml}$ of trichloroacetic acid (TCA)-thiobarbituric acid (TBA) reagent (equal volumes of TCA- $2.8 \%$ and TBA- $0.5 \%$ in 4 $\mathrm{mM} \mathrm{NaOH}$ ) was added which is followed by boiling the tubes in a water bath for $30 \mathrm{~min}$. At $532 \mathrm{~nm}$, absorbance was recorded once cooling of the tubes and mannitol was used as standard [15].

\section{Acute toxicity study}

Toxicity of endophytic fractions of Phyllanthus niruri Linn in albino Wistar rats will be determined as per reported method. All animals will be given endophytic fractions by oral route, and for next $3 \mathrm{~h}$ animals will be observed for mortality and behavioral changes. Animals will be observed for next $48 \mathrm{~h}$ for any mortality. $\mathrm{LD}_{50}$ will be calculated according to the guidelines of OECD.

\section{Hepatoprotective activity Procedure}

Animals were above grouped as shown above and treated for 5 days (Table 1). On the 2nd and 3rd day $\mathrm{CCl} 4$ ( $2 \mathrm{ml} / \mathrm{kg}$ i.p.) in olive oil was administered to all groups other than group I. Silymarin $25 \mathrm{mg} / \mathrm{kg}$ p.o. was received as standard drug once in a day and $\mathrm{CCl}_{4}$ as per above for group III. Whereas, group IV and $\mathrm{V}$ were

\begin{tabular}{|c|c|c|}
\hline Sr. No. & Groups & Details of groups \\
\hline 1 & Group 1 & $\begin{array}{l}\text { Normal control rats treated with } 0.9 \% \mathrm{NaCl} \\
{[2 \mathrm{ml} / \mathrm{kg} \text { day] }}\end{array}$ \\
\hline 2 & Group 2 & Rats treated with $\mathrm{CCl}_{4}(2 \mathrm{ml} / \mathrm{kg}$ i.p. in olive oil) \\
\hline 3 & Group 3 & $\begin{array}{l}\text { Rats treated with Silymarin ( } 25 \mathrm{mg} / \mathrm{kg} \text { p.o.) } \\
+\mathrm{CCl}_{4}\end{array}$ \\
\hline 4 & Group 4 & $\begin{array}{l}\text { Rats treated with fraction PNFC ( } 50 \mathrm{mg} / \mathrm{kg} \text { p.o.) } \\
+\mathrm{CCl}_{4}\end{array}$ \\
\hline 4 & Group 5 & $\begin{array}{l}\text { Rats treated with fraction PNFC (100mg/kg p.o.) } \\
+\mathrm{CCl}_{4}\end{array}$ \\
\hline 6 & Group 6 & $\begin{array}{l}\text { Rats treated with fraction PNFEA ( } 50 \mathrm{mg} / \mathrm{kg} \text { p.o.) } \\
+\mathrm{CCl}_{4}\end{array}$ \\
\hline 7 & Group 7 & $\begin{array}{l}\text { Rats treated with fraction PNFEA ( } 100 \mathrm{mg} / \mathrm{kg} \text { p.o.) } \\
+\mathrm{CCl}_{4}\end{array}$ \\
\hline
\end{tabular}


treated with fractions PNEAF with $(50$ and $100 \mathrm{mg} / \mathrm{kg}$ p.o. each group) and group VI and VII were treated with fractions PNCF with a dose of 50 and $100 \mathrm{mg} / \mathrm{kg}$ p.o. each group, respectively. During this period of treatment, the rats were maintained under normal diet and water. On the 6th day, all animals were sacrificed and blood samples were collected by retro-orbital bleeding which was centrifuged for $15 \mathrm{~min}$ at $3000 \mathrm{rpm}$ and used for biochemical evaluation. The liver was dissected out and subjected for morphological study such as wet liver weight of each animal. Further histopathological study of liver was performed. Then, the liver homogenate was subjected for in vivo antioxidant estimation [16].

\section{Estimation of biochemical parameters} Estimation of serum SGPT (IFCC method)

Alanine transaminase (ALT) also known as SGPT located in cytosol of liver cell. At elevated permeability of cell membrane, SGPT was released in blood circulation due to inflammation and break down of liver cells. Hence, determination of ALT is a sign of the extent of liver damage. Pyruvate and L-glutamate was produced after catalysis transfer of amino group from L-alanine to 2-oxoglutarate by SGPT. L-lactate was produced by reaction of pyruvate and NADH. Decrease in absorbance of NADH at $340 \mathrm{~nm}$ is indicative of oxidation of NADH equivalent to potency of SGPT action [17].

\section{Estimation of SGOT/AST}

The reaction of 2-oxoglutarate and L-aspartate was catalyzed by aspartate transaminase which gives product of glutamate and oxaloacetate. In the presence of malate dehydrogenase oxaloacetate react with NADS gives NAD and malate. SGOT activity is directly proportional to decrease in rate of NADH which is mainly calculated photometrically [18].

\section{Estimation of serum alkaline phosphate (SALP)}

Serum alkaline phosphatase hydrolyses p-nitrophenyl phosphate into p-nitrophenol and phosphate due to oxidizing agent $\mathrm{Mg++}$. This reaction is measured as absorbance is proportional to the SALP activity [19].

\section{Estimation of bilirubin}

Azobilirubin was produced by reaction of bilirubin with sulphanilic acid diazotized in acidic medium. Absorbance of azobilirubin gives exact concentration of bilirubin. In an acidic medium, bilirubin directly reacts because of its water solubility. However, surfactant solubilizer bilirubin is solubilized [20].

\section{Lipid peroxidation (LPO)}

TBARS (thiobarbituric acid reactive substances) in liver homogenate was estimated by using standard protocol.
Homogenate was incubated with 15\% TCA, $0.375 \%$ TBA, and $5 \mathrm{~N} \mathrm{HCl}$ at 95 against blank. LPO was determined and represented as TBARS (micromoles) per gram of tissue [20].

\section{Estimation of cholesterol}

At the end of the reaction quinoneimine whose absorbance gives direct concentration of cholesterol [21].

Cholesterol ester ALP $\rightarrow$ Cholesterol+ fatty acid

Cholesterol $+\mathrm{O}_{2}$ CHOD $\rightarrow$ Cholest-4-en-3-one $+\mathrm{H} 2 \mathrm{O} 2$

$2 \mathrm{H} 2 \mathrm{O} 2+4 \mathrm{AAP}+$ phenol $\rightarrow$ POD4H2O + Quinoneimine

\section{Estimation of total protein}

In alkaline solution, copper ion reacts with peptide bonds of protein to produce blue-violet complex. Five to 6 peptide bonds are complexed with each copper ion. Tartrate was added as stabilizer and auto-reduction of protein concentration is prevented by iodide measured at $546 \mathrm{~nm}$.

\section{Identification and characterization of fungal endophyte $P C R$ amplification and DNA extraction}

The genomic DNA was isolated from the given organism using genomic DNA extraction Kit (Bhat Biotech)

\section{Phenotypic identification}

The colonies grown on the plate were studied by the colony characteristics and Lacto phenol cotton blue staining. The significant parameters compared with the standard organisms from the literature.

\section{$P C R$ amplification and sequencing}

The amplification was performed in PCR tube using Master cycler Thermo cycle (DNA mp Bhat Biotech). PCR products were purified from ITS gene with help of Gen easy gel elution kit, Bhat Biotech India Pvt. Ltd. Both strands of the rDNA region amplified by PCR were sequenced by automated DNA sequence -3037x l DNA analyzer [22].

\section{Results}

Isolation and Identification of endophytes from Phyllanthus niruri Linn.

PCR and BLAST analysis studies conforms that two isolated endophytic fungi were isolated from Phyllanthus niruri Linn., identified as Aspergillus niger strain A6 PNLF (leaf endophyte) and Eurotium amstelodami strain CASMB-SEF 9 PNSF (stem endophyte), respectively (Fig. 1). Genomic sequence of both endophytic fungi PNLF and PNSF was identified and by using rDNA sequential analysis and $16 \mathrm{sr}$ RNA gene amplification which matches with standard genomic sequence of fungi (Fig. 2). In the 

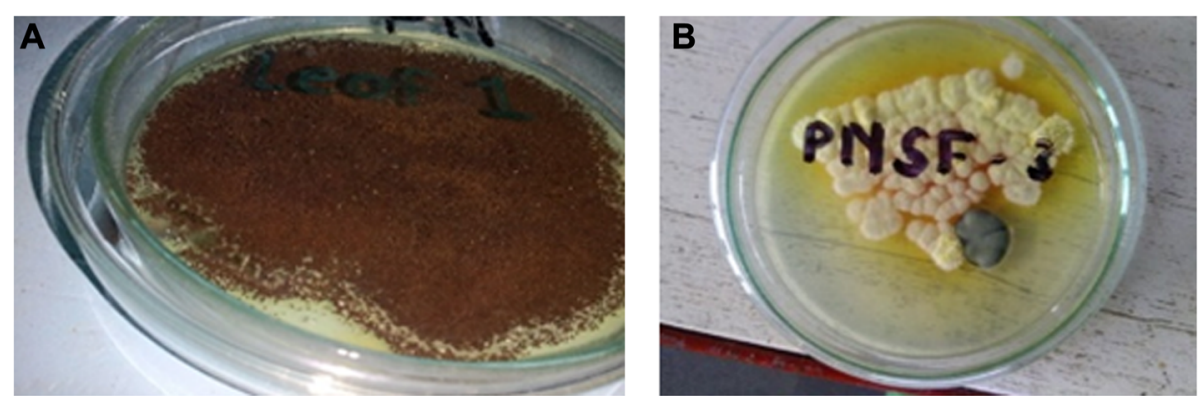

Fig. 1 Endophytic fungi a PNLF and $\mathbf{b}$ PNSF of Phyllanthus niruri Linn.

present investigation, Eurotium amstelodami strain CASMB-SEF 9 was isolated from stem segment of Phyllanthus niruri Linn. and was screened for in vitro antioxidant and in vivo hepatoprotective potential (Fig. 3).

\section{Sequencing of the PCR amplicon of the 16s RNA gene (PNLF) \\ ITS $F$}

TTGCTTCGGGTGCGGGTCTTTGGGCCACCTCCCA TCCGTGTCTATTGTACCCTGTTGCTTCGGCGG GCCCGCCGCTTGTCGGCCGCCGGGGGGGCGCC TCTGCCCCCCGGGCCCGTGCCCGCCGGAGACC CCAACACGAACACTGTCTGAAAGCGTGCAGTC TGAGTTGATTGAATGCAATCAGTTAAAACTTTCA ACAATGGATCTCTTGGTTCCGGCATCGATGAAGA ACGCAGCGAAATGCGATAACTAATGTGAATTG CAGAATTCAGTGAATCATCGAGTCTTTGAACG CACATTGCGCCCCCTGGTATTCCGGGGGGCATGC CTGTCCGAGCGTCATTGCTGCCCTCAAGCCCGGC TTGTGTGTTGGGTCGCCGTCCCCCTCTCCGGG GGGACGGGCCCGAAAGGCAGCGGCGGCACCGC GTCCGATCCTCGAGCGTATGGGGCTTTGTCAC

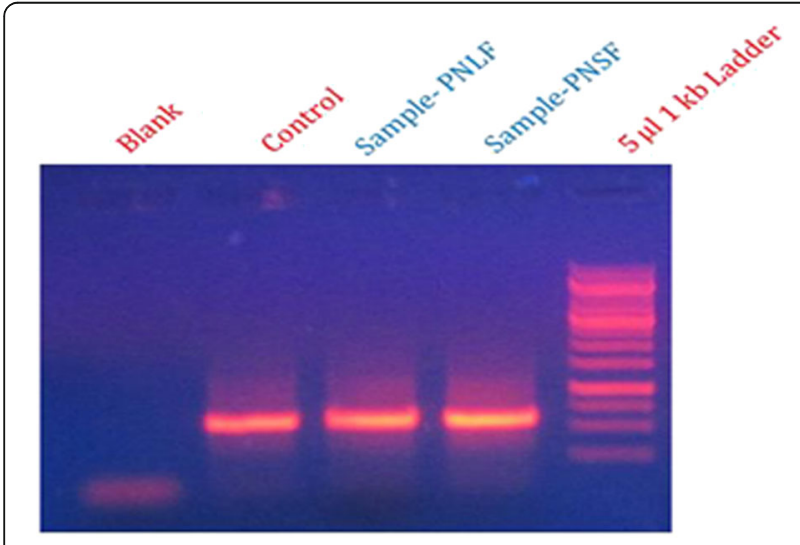

$1 \%$ Agarose gel Run at $100 \mathrm{~V}$

Fig. 2 Genomic DNA isolation and PCR amplification of the 16sr RNA gene
ATGCTCTGTAGGATTGGCCGGCGCCTGCCGAC GTTTTCCAACCATTCTTTCCAGGTTGACCTCG GATCAGGTAGGGATACCCGCTGAACTTAAGCA TATCAATAAGCGGAGGAATTCCGAGGGACGCT CCCTTCTAGCAAGCACCAATTCT

\section{ITS R}

ATACAGGGGGACGCCCTTAGCACCTACAGCTTCC GTAGGGTGAACCTGCGGAAGGATCATTACCGA GTGCGGGTCCTTTGGGCCCAACCTCCCATCCGTG TCTATTGTACCCTGTTGCTTCGGCGGGCCCGCCG CTTGTCGGCCGCCGGGGGGGCGCCTCTGCCCC CCGGGCCCGTGCCCGCCGGAGACCCCAACACGAACACTGTCTGAAAGCGTGCAGTCTGAGTTGA TTGAATGCAATCAGTTAAAACTTTCAACAATGGA TCTCTTGGTTCCGGCATCGATGAAGAACGCAGCG AAATGCGATAACTAATGTGAATTGCAGAATTC AGTGAATCATCGAGTCTTTGAACGCACATTGC GCCCCCTGGTATTCCGGGGGGCATGCCTGTCCGA GCGTCATTGCTGCCCTCAAGCCCGGCTTGTGTGT TGGGTCGCCGTCCCCCTCTCCGGGGGGACGGG CCCGAAAGGCAGCGGCGGCACCGCGTCCGATC CTCGAGCGTATGGGGCTTTGTCACATGCTCTG TAGGATTGGCCGGCGCCTGCCGACGTTTTCCA ACCATTCTTCCAGGTGACCTCGGATCAGGTAA GGGTACCAATGC
Sequencing of the PCR amplicon of the 16s RNA gene (PNSF)
ITS F
GGGCAACGAGTGCGGACTCTGGGTCCACCTCC CATCCGTGTCTATCTGTACCCTGTTGCTTCGGCG TGGCCACGGCCCGCCGGAGACTAACATTTGAA CGCTGTCTGAAGTTTGCAGTCTGAGTTTTTAG TTAAACAATCGTTAAAACTTTCAACAACGGATCT CTTGGTTCCGGCATCGATGAAGAACGCAGCGA AATGCGATAATTAATGTGAATTGCAGAATTCAGT GAATCATCGAGTCTTTGAACGCACATTGCGCC CCCTGGTATTCCGGGGGGCATGCCTGTCCGAG CGTCATTGCTGCCCTCAAGCACGGCTTGTGTG TTGGGCTTCCGTCCCTGGCAACGGGGACGGGC 

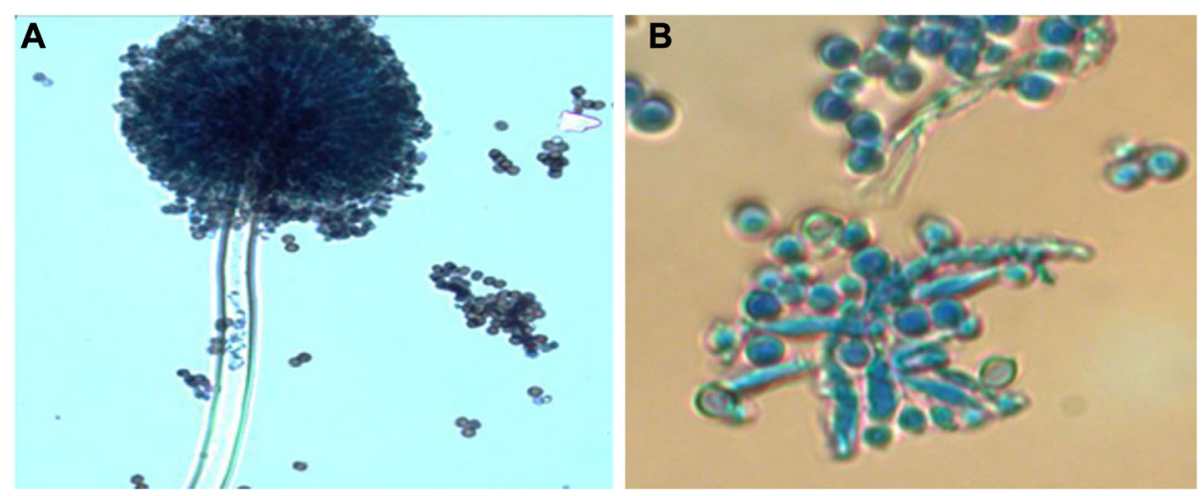

Fig. 3 Microscopic view of a Aspergillus niger A6 and $\mathbf{b}$ Eurotium amstelodami CASMB-SEF 9

CCAAAAGGCAGTGGCGGCACCATGTCTGGTCC TCGAGCGTATGGGGCTTTGTCACCCGCTCCCG TAGGTCCAGCTGGCAGCTAGCCTCGCAACCAA TCTTTTTAACCAGGTTGACCTCGGATCAGGTAGG GATACCCGCTGAACTTAAGCATATCAATAAGC CGGGAGGAATCCTTACGCCTGTCTTCC

\section{ITS R}

GAAACCAGCATGGTGGGTGGGGTGCACCGAGG GGGCCCACCCCGGAAAGAACCCCTCCCGTAGG GGGGACCTGCGGAAGGATCATTACCGAGTG CGGGCCCTCTGGGTCCAACCTCCCATCCGTGTCT ATCTGTACCCTGTTGCTTCGGCGTGGCCACGGCC CGCCGGAGACTAACATTTGAACGCTGTCTGAA GTTTGCAGTCTGAGTTTTTAGTTAAACAATCG TTAAAACTTTCAACAACGGATCTCTTGGTTCC GGCATCGATGAAGAACGCAGCGAAATGCGATA ATTAATGTGAATTGCAGAATTCAGTGAATCAT CGAGTCTTTGAACGCACATTGCGCCCCCTGGT ATTCCGGGGGGCATGCCTGTCCGAGCGTCATT GCTGCCCTCAAGCACGGCTTGTGTGTTGGGCT TCCGTCCCTGGCAACGGGGACGGGCCCAAAAG GCAGTGGCGGCACCATGTCTGGTCCTCGAGCG
TATGGGGCTTTGTCACCCGCTCCCGTAGGTCC AGCTGGCAGCTAGCCTCGCAACCAATCTTTTT AACCAGGTGACCTCGGATCAGTAGGTCCGTTC

In vitro steady-state free radical scavenging studies PNFC and PNFEA showed DPPH scavenging activity with $\mathrm{IC}_{50}$ of $97.79 \mu \mathrm{g} / \mathrm{ml}$ and $108.40 \mu \mathrm{g} / \mathrm{ml}$, respectively, as compared to standard ascorbic acid having $\mathrm{IC}_{50}$ of $21.74 \mu \mathrm{g} / \mathrm{ml}$ (Fig. 4). The ability of the PNFC and PNFEA to scavenge the hydroxyl radicals generated through Fenton reaction as measured by the degradation of deoxy-D-ribose yielding malondialdehide (MDA) was measured as TBARS. Both PNFC and PNFEA have concentration-dependent $\mathrm{OH}$ scavenging activity with $\mathrm{IC}_{50}$ value $433.19 \mu \mathrm{g} / \mathrm{ml}$ and 440 $\mu \mathrm{g} / \mathrm{ml}$, respectively, compared to standard mannitol which showed an $\mathrm{IC}_{50}$ of $185.5 \mu \mathrm{g} / \mathrm{ml}$ (Fig. 5). Results of scavenging activity conforms concentrationdependent activity of PNFC and PNFEA fractions. As concentration increases percentage absorbance also increased when compared to standard ascorbic acid which is indicative of both fractions possess strong reducing power activity (Fig.6).
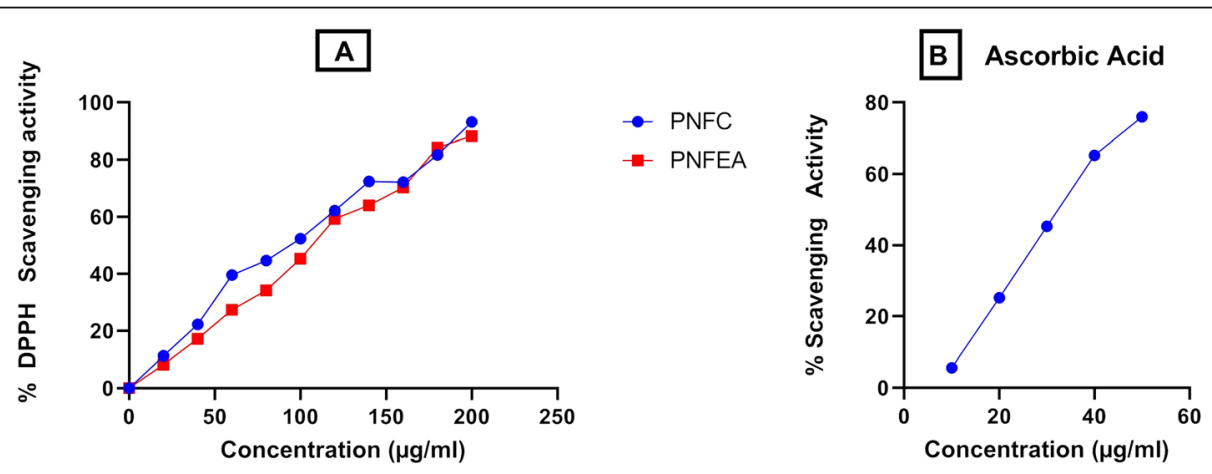

Fig. 4 DPPH radicals scavenging activity of a PNFC and PNFE (b) ascorbic acid 
A

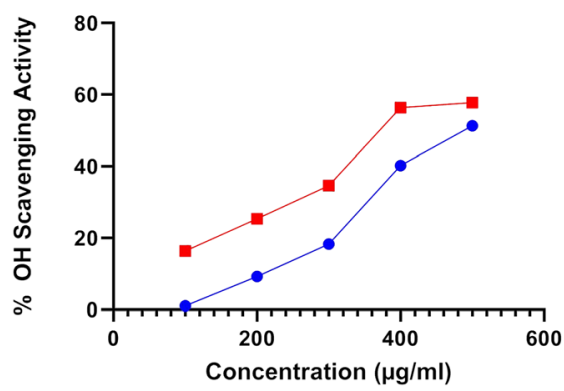

B Mannitol
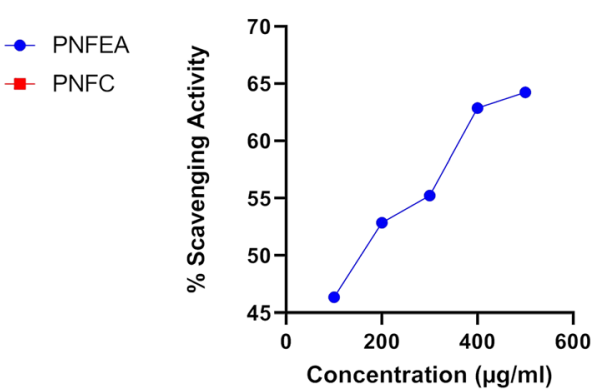

Fig. 5 Hydroxyl scavenging activity of a PNFC and PNFEA (b) mannitol

\section{Hepatoprotective activity}

Acute toxicity studies ( $\left.L D_{50}\right)$

The endophytic fractions PNFC and PNFEA were subjected to acute toxicity studies as per OECD guidelines (up and down method). Phyllanthus niruri Linn. stem did not show any toxicity and behavioral changes, and no mortality was observed in mice up to $2000 \mathrm{mg} / \mathrm{kg}$ and hence, doses of $50 \mathrm{mg} / \mathrm{kg}$ and $100 \mathrm{mg} / \mathrm{kg}$ were selected for hepatoprotective activity.

\section{Evaluation of hepatoprotective activity \\ Effect of PNFC and PNFEA on biochemical markers in $\mathrm{CCl}_{4}-$ induced hepatotoxicity}

The administration of $\mathrm{CCl}_{4}$ leads to significant hepatocellular damage as evident from the increase in serum activities of SGPT $\left(80.14 \pm 0.13^{* * *}\right)$, SGOT (140 \pm $\left.6.73^{* *}\right)$, SLAP $\left(566.2 \pm 0.4^{* * *}\right)$, total bilirubin $(0.21 \pm$ $0.019 *)$, direct bilirubin $\left(0.04 \pm 0.004^{* *}\right)$, total cholesterol $\left(79.06 \pm 0.82^{* * * *}\right)$, proteins $\left(6.23 \pm 0.07^{* *}\right)$, and LPO $(0.15$ $\left.\pm 0.005^{* * * *}\right)$ along with decrease in level of CAT $(0.11 \pm$ $\left.0.006^{* * * *}\right)$ and SOD $\left(0.15 \pm 0.02^{* * * *}\right)$ in comparison to normal control group.

Treatment with PNFC fraction at dose of $100 \mathrm{mg} / \mathrm{kg}$ p.o. exhibited significant reduction of induced elevation of serum SGPT $\left(42.66 \pm 1.69^{* * * *}\right)$, SGOT $\left(103 \pm 4.82^{* *}\right)$,
SLAP $\left(434.32 \pm 0.5^{* * *}\right)$, total bilirubin $\left(0.09 \pm 0.011^{*}\right)$, direct bilirubin $(0.013 \pm 0.002)$, total cholesterol $(69.43 \pm$ $0.70)$, proteins $\left(5.30 \pm 0.07^{* *}\right)$, and LPO $\left(0.11 \pm 0.001^{* * *}\right)$ along with increase in level of CAT $\left(0.21 \pm 0.006^{* * *}\right)$ and SOD $(0.30 \pm 0.02 \%)$ as illustrated in Tables 2 and 3 .

Treatment with PNFEA fraction at dose of $100 \mathrm{mg} / \mathrm{kg}$ p.o. exhibited significant reduction of induced elevation of serum SGPT $\left(42.51 \pm 2.41^{* * *}\right)$, SGOT $\left(108 \pm 1.83^{*}\right)$, SLAP $\left(409.4 \pm 0.68^{* *}\right)$, total bilirubin $(0.07 \pm 0.005)$, direct bilirubin $(0.02 \pm 0.003)$, total cholesterol (71.73 \pm $0.40)$, proteins $\left(5.31 \pm 0.06^{* *}\right)$, and LPO $\left(0.12 \pm 0.005^{*}\right)$ along with increase in level of CAT $\left(0.25 \pm 0.01^{*}\right)$ and SOD $(0.32 \pm 0.02 *)$ as illustrated in Tables 2 and 3 . Treatment with standard silymarin also responded well and reduced hepatotoxicity However, both fractions PNFC and PNFEA produced hepatoprotective activity in a dose-dependent manner. Comparative study of effect of PNFC and PNFEA on normal control, standard silymarin, and $\mathrm{CCl}_{4}$ in different serum biochemical parameters is illustrated in Tables 2 and 3.

\section{Hepatoprotective activity of PNFC and PNFEA}

(A) In histopathology of normal rat liver is the liver of a control rat showing normal hepatocytes and normal architecture. (B) Rat liver histopathology in $\mathrm{CCl}_{4^{-}}$ treated group shows focal hemorrhage, inflammation,

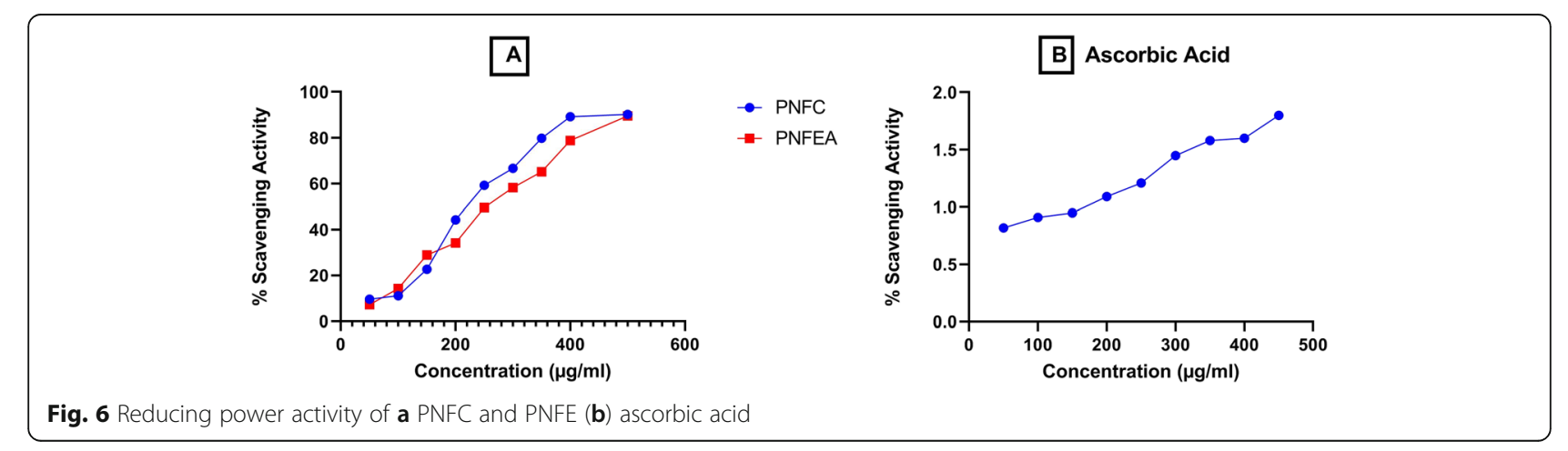




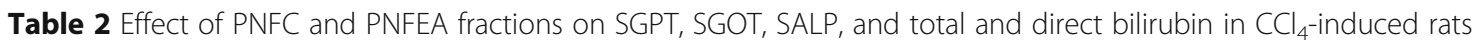

\begin{tabular}{lllllll}
\hline Groups & Dose $(\mathbf{m g} / \mathbf{k g})$ & SGPT $(\mathbf{m g} / \mathbf{d l})$ & SGOT $(\mathbf{m g} / \mathbf{d l})$ & SALP $(\mathbf{m g} / \mathbf{d l})$ & Total bilirubin $(\mathbf{m g} / \mathbf{d l})$ & Direct bilirubin $(\mathbf{m g} / \mathbf{d l})$ \\
\hline Control & $2 \mathrm{ml} / \mathrm{kg}$ & $39.10 \pm 0.27$ & $105 \pm 0.67$ & $458.1 \pm 0.9$ & $0.045 \pm 0.007$ & $0.015 \pm 0.002$ \\
CCl4 treated & $2 \mathrm{ml} / \mathrm{kg}$ & $80.14 \pm 0.13^{* * *}$ & $140 \pm 6.73^{* *}$ & $566.2 \pm 0.4^{* * *}$ & $0.21 \pm 0.019^{*}$ & $0.04 \pm 0.004^{* *}$ \\
Silymarin & $25 \mathrm{mg} / \mathrm{kg}$ & $44.44 \pm 2.08^{* * *}$ & $96.5 \pm 0.9^{*}$ & $406.2 \pm 1.1^{* * *}$ & $0.13 \pm 0.010$ & $0.018 \pm 0.003$ \\
PNFC & $50 \mathrm{mg} / \mathrm{kg}$ & $50.75 \pm 2.51^{* * *}$ & $111 \pm 2.83^{*}$ & $336.7 \pm 0.9^{* * *}$ & $0.12 \pm 0.010$ & $0.03 \pm 0.002^{* * *}$ \\
PNFC & $100 \mathrm{mg} / \mathrm{kg}$ & $42.66 \pm 1.69^{* * *}$ & $103 \pm 4.82^{* *}$ & $434.32 \pm 0.5^{* * *}$ & $0.09 \pm 0.011^{*}$ & $0.013 \pm 0.002$ \\
PNFEA & $50 \mathrm{mg} / \mathrm{kg}$ & $53.92 \pm 1.35^{* * *}$ & $114 \pm 0.10^{*}$ & $385.3 \pm 0.8^{* * *}$ & $0.14 \pm 0.014$ & $0.03 \pm 0.002$ \\
PNFEA & $100 \mathrm{mg} / \mathrm{kg}$ & $42.51 \pm 2.41^{* * *}$ & $108 \pm 1.83^{*}$ & $409.4 \pm 0.68^{* *}$ & $0.07 \pm 0.005$ & $0.02 \pm 0.003$
\end{tabular}

The data were expressed as mean \pm S.E.M. for six rats in each group. Statistical comparison was performed by one-way ANOVA followed by Turkey's post test $* P<0.05,{ }^{*} P<0.01$, and $* * P<0.001$ compared to normal control-treated group

ballooning hepatocytes, apoptosis, and degeneration stained with hematoxyline-eosine. (C) Rat liver histopathology in silymarin $(25 \mathrm{mg} / \mathrm{kg})$ treated group shows no focal hemorrhage stained with hematoxyline-eosine. (D) Rat liver histopathology in PNFC (50 mg/ $/ \mathrm{kg}$ )-treated group shows no focal hemorrhage and slight ballooning hepatocytes stained with hematoxyline-eosine. (E) Rat liver histopathology in PNFC (100 mg/kg)-treated group shows no focal hemorrhage and slight ballooning hepatocytes stained with hematoxyline-eosine. (F) Rat liver histopathology in PNFEA $(50 \mathrm{mg} / \mathrm{kg})$ treated group shows mild degeneration and reverting to regeneration, stained with hematoxyline-eosine. (G) Rat liver histopathology in PNFEA (100 $\mathrm{mg} / \mathrm{kg})$-treated group shows complete regeneration and normal architecture of hepatocytes stained with hematoxyline-eosine (Fig. 7).

\section{Discussion}

Endophytic fungi Eurotium amstelodami was identified and conformed by PCR sequential analysis which is a type of soil borne fungus. These Eurotium species mainly occurs in grain products, poultry feed, bakery products, dried fruits, spices, soil, hypersaline waters, and Dead Sea soil. E. amstelodami produced neoechinulin-A and neoechinulin-B as major metabolites $[23,24] . \mathrm{IC}_{50}$ is a good measure of antioxidant potential of both endophytic fractions PNFC and PNFEA showed DPPH scavenging activity with $\mathrm{IC}_{50}$ of $97.79 \mu \mathrm{g} / \mathrm{ml}$ and $108.40 \mu \mathrm{g} / \mathrm{ml}$, respectively. Damage to the liver cells by $\mathrm{CCl}_{4}$ mainly involves metabolism of $\mathrm{CCl}_{4}$ to trichlromethyl free radical by the mixed function oxidase system of the endoplasmic reticulum. It is postulated that secondary mechanism links $\mathrm{CCl}_{4}$ metabolism to the wide spread disturbance in hepatocyte function. These secondary mechanisms mainly responsible for the generation of toxic product arising directly from $\mathrm{CCl}_{4}$ metabolism [25]. In the presence of oxygen, auto-oxidation of the fatty acids occurs in the cytoplasmic membrane which was mediated by free radicals [26]. Functional along with morphological variations in cell membrane occurs due to phospholipids. Furthermore, entry of extracellular $\mathrm{Ca}^{++}$ions into cells causes hepatic cell death which produce and release high concentration of SGOT and SGPT in the blood. Total protein, bilirubin, and SALP concentration represents liver function of hepatocyte. Protein level gives a clue regarding hepatoprotective potential as fall in protein level indicates cellular dysfunction in liver diseases and rapid biosynthesis of proteins promote regeneration of hepatocytes which conforms hepatoprotective potential [27]. Bilirubin and SALP levels are indicative of severity of cell death and biliary pressure. Elevated level above normal of total bilirubin produces hepatocellular dysfunction and rapid rise of biliary pressure due to increase in synthesis of SALP [28]. Significant increase $(p<0.01)$ of total proteins

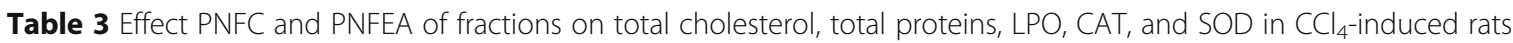

\begin{tabular}{lllllll}
\hline Groups & Dose $(\mathbf{m g} / \mathbf{k g})$ & $\begin{array}{l}\text { Total cholesterol } \\
(\mathbf{m g} / \mathbf{d l})\end{array}$ & $\begin{array}{l}\text { Total proteins } \\
(\mathbf{m g} / \mathbf{d l})\end{array}$ & $\begin{array}{l}\text { LPO level } \\
(\boldsymbol{\mu m o l} / \mathbf{m g} \text { protein) }\end{array}$ & $\begin{array}{l}\text { CAT level } \\
(\boldsymbol{\mu m o l} / \mathbf{m g} \text { protein) }\end{array}$ & $\begin{array}{l}\text { SOD level } \\
(\boldsymbol{\mu m o l} / \mathbf{m g} \text { protein) }\end{array}$ \\
\hline Control & $2 \mathrm{ml} / \mathrm{kg}$ & $69.83 \pm 0.30$ & $5.78 \pm 0.04$ & $0.09 \pm 0.003$ & $0.32 \pm 0.008$ & $0.48 \pm 0.009$ \\
CCl4 treated & $2 \mathrm{ml} / \mathrm{kg}$ & $79.06 \pm 0.82^{* * *}$ & $6.23 \pm 0.07^{* *}$ & $0.15 \pm 0.005^{* * *}$ & $0.11 \pm 0.006^{* * *}$ & $0.15 \pm 0.02^{* * *}$ \\
Silymarin & $25 \mathrm{mg} / \mathrm{kg}$ & $65.15 \pm 0.98$ & $5.46 \pm 0.08$ & $0.09 \pm 0.0006^{* *}$ & $0.18 \pm 0.002^{*}$ & $0.28 \pm 0.022^{* * *}$ \\
PNFC & $50 \mathrm{mg} / \mathrm{kg}$ & $73.29 \pm 0.82$ & $5.36 \pm 0.04^{* *}$ & $0.11 \pm 0.004^{*}$ & $0.15 \pm 0.01^{* *}$ & $0.26 \pm 0.015^{* *}$ \\
PNFC & $100 \mathrm{mg} / \mathrm{kg}$ & $69.43 \pm 0.70$ & $5.30 \pm 0.07^{* *}$ & $0.10 \pm 0.001^{* * *}$ & $0.21 \pm 0.006^{* *}$ & $0.30 \pm 0.02^{* * *}$ \\
PNFEA & $50 \mathrm{mg} / \mathrm{kg}$ & $73.49 \pm 0.98$ & $6.07 \pm 0.05^{*}$ & $0.12 \pm 0.001^{*}$ & $0.21 \pm 0.07^{* * *}$ & $0.31 \pm 0.014^{* *}$ \\
PNFEA & $100 \mathrm{mg} / \mathrm{kg}$ & $71.73 \pm 0.40$ & $5.31 \pm 0.06^{* *}$ & $0.10 \pm 0.005^{*}$ & $0.25 \pm 0.01^{*}$ & $0.32 \pm 0.02^{* *}$ \\
\hline
\end{tabular}

The data were expressed as mean \pm S.E.M. for six rats in each group. Statistical comparison were performed by one-way ANOVA followed by Turkey's post test ${ }^{*} P<0.05,{ }^{* *} P<0.01$, and ${ }^{* *} P<0.001$ compared to normal control-treated group 

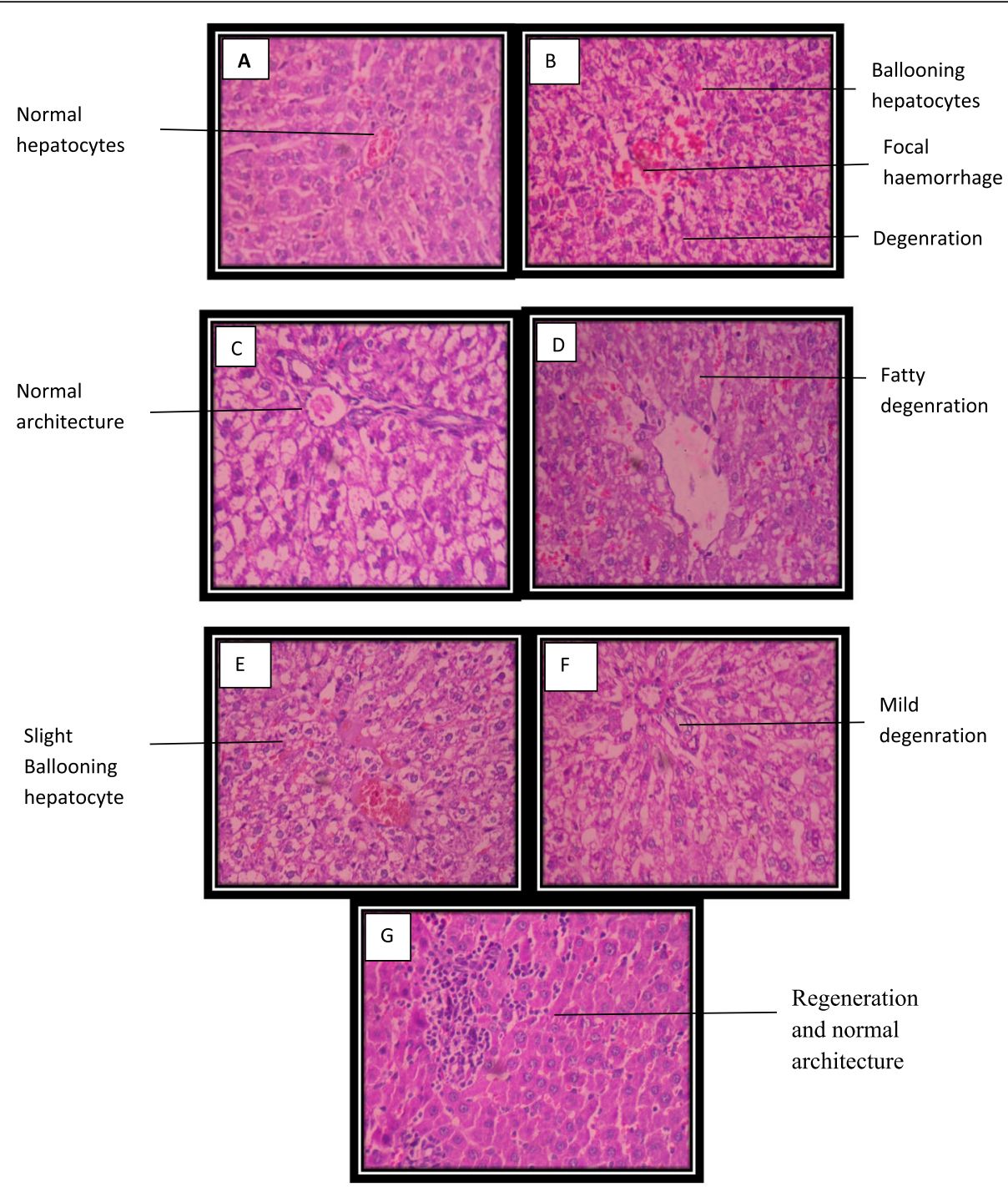

Fig. 7 Effect of PNFC and PNFEA on liver of different groups of rats

observed in $\mathrm{CCl}_{4}$-treated group compared with the normal control rats while group treated with PNFC and PNFEA showed significant decrease $(p<0.05 ; p<0.01)$, respectively, of total proteins in comparison with the $\mathrm{CCl}_{4}$-treated group. Like standard silymarin-treated group with PNFC and PNFEA, silymarin stimulated the rate of protein biosynthesis in hepatocyte and enhanced the generation and production process of liver cells. $\mathrm{CCl}_{4}$-treated group showed rapid increase of bilirubin and SALP $(p<$ $0.01 ; p<0.001)$, respectively, when compared to normal control group. These results indicate that $\mathrm{CCl}_{4}$ induces hepatobiliary disease and group treated with both endophytic fractions showed decrease $(p<0.05 ; p<0.01)$ of total bilirubin in comparison with $\mathrm{CCl}_{4}$-treated group which is very much similar to the silymarin-treated group. These finding strongly indicate both endophytic fractions have hypobilirubin activity [29]. $\mathrm{CCl}_{4}$-treated group showed significant increase in total cholesterol level in liver and induce cholesterol deposition which produce adverse effects on the liver tissues and cardiovascular system [24]. Treatment with both endophytic fungi PNFC and PNFEA showed significant decrease in total cholesterol level $(p<0.05 ; p<0.01)$, respectively, was observed. Results strongly suggest both endophytic fungi strongly enhance capacity of endogenous enzyme to destroy or capture reactive oxygen species (ROS) and prevent the occurrence of certain pathological conditions [30]. After treatment with $\mathrm{CCl}_{4}$, lipid peroxidation has been destructive process in liver injury. Malondialdehide (MDA) is the end product of lipid peroxidation. Rise of MDA in liver cells which is sing of lipid peroxidation has taken place and incapability of antioxidant defense system to prevent formation of many free radicals and is there for liver tissue damage [31]. Rise in inflammatory signals during the lipid 
peroxidation process which are markedly inhibited by both endophytic fractions and silymarin. $\mathrm{CCl}_{4}$-treated group showed significant increase $(p<0.001)$ of MDA level compared to normal control group which is rapidly reduced in rats treated with PNFC and PNFEA $(p<0.05$; $p<0.01$ ), respectively, and silymarin. Hepatoprotective activity is mainly an indication of its protective effects to reduce the injurious and maintain normal hepatic mechanism which is disturbed by hepatotoxins [32]. SOD and CAT are antioxidant enzymes used to remove reactive oxygen species which produces oxidative stress results in liver injury. CAT possess protective potential against the tissue from hydroxyl radicals by converting $\mathrm{H}_{2} \mathrm{O}_{2}$ in to water and oxygen [33]. Reduced potential of CAT and SOD indicate hepatic damage in $\mathrm{CCl}_{4}$-treated group. In present investigation, PNFC and PNFEA significantly increase SOD $(p<0.05 ; p<0.01)$ and CAT activities $(p<$ $0.01 ; p<0.001)$, respectively. The restoration of tissue activities of SOD and CAT confirms the protective mechanism of both endophytic fractions. PNFC and PNFEA (100 $\mathrm{mg} / \mathrm{kg}$ ) of Phyllanthus niruri Linn. rise in depleted enzyme level induced by $\mathrm{CCl}_{4}$ confirms hepatoprotective potential by regeneration of damaged liver cells. Both endophytic fungi are capable of maintaining the activity of hepatic enzymes which are involved in combating reactive oxygen species. The hepatoprotective action of Phyllanthus niruri Linn. endophyte was evidenced by the amelioration of biochemical indicators of liver damage and pathological disturbances caused by $\mathrm{CCl}_{4}$.

\section{Conclusion}

From the results, we can conclude that Phyllanthus niruri Linn. stem fraction protects the liver from oxidative damage and could be used as an effective protector in $\mathrm{CCl}_{4}$-induced damage. The potent antioxidant and hepatoprotective potential of PNFC and PNFEA may be due to the secondary metabolites of fungi, i.e., Eurotiumam stelodami strain. The present investigation has also opened avenues for further research in pharmacological studies especially endophytes from medicinal plants in development of potent biomedicine for treatment of various chronic diseases.

\footnotetext{
Abbreviations

CCl4: Carbon tetrachloride; PNFC: Chloroform fraction of Phyllanthus niruri L. fungi; PNFEA: Ethyl acetate fraction of Phyllanthus niruri L. fungi; SGPT: Serum Glutamate Pyruvate Transaminase; SGOT: Serum Glutamate Oxaloacetate Transaminase; SALP: Serum Alkaline phosphatase; TC: Total cholesterol; LPO: Lipid peroxidation; TBARS: Thiobarbituric acid reactive substances; OECD: Organization for Economic Co-operation and Development; DPPH: 2,2diphenyl-1-picrylhydrazyl; OH: Hydroxyl; PO: Per Oral; MDA: Malondialdehide; mg/kg: Milligram/kilogram; PNLF: Phyllanthus niruri Linn. leaf fungi; PNSF: Phyllanthus niruri Linn. Stem fungi; CPCSEA: Committee for Purpose of Control and Supervision on Experiments on Animals; SEM: Standard error of mean; IAEC: Institutional animal Ethical Committee
}

\section{Acknowledgements}

Authors are thankful to Principal Sonia Educational Trusts College of Pharmacy, Dharwad, Principal Sant Gajanan Maharaj College of Pharmacy Mahagaon, and Trustees of Sant Gajanan Maharaj College of Pharmacy Mahagaon for providing required facilities, guidance, and support to complete present research work.

\section{Plant source}

The whole plant of Phyllanthus niruri Linn. family (Phyllanthaceae) was collected from Dharwad identified and authenticated by Dr. G.R. Hegde Karnatak University, Dharwad, Karnataka (India), and the voucher specimen no. SETCPD/PH.COG/HERB/05-2016 of herbarium was deposited in the Department of Botany Karnataka University, Dharwad, Karnataka.

\section{Authors' contributions}

RK and SG are the researchers who carried out isolation and all research activities related to endophytes, and SG and DB have major contributors in writing the manuscript. SK and SP are the supervisors who guided in isolation and characterization of endophytes, and PH has major contributions in monitoring pharmacological studies and writing discussion. All authors read and approved the final manuscript.

Funding

No funding was obtained for this study.

\section{Availability of data and materials}

The data sets used and/or analyzed during current research work are available from the corresponding author on reasonable request.

\section{Declarations}

\section{Ethics approval and consent to participate}

All animal studies were approved by the Institutional Animal Ethical Committee (IAEC) of Sonia Educational Trusts College of Pharmacy, Dharwad, Karnataka (reg. No. 112/PO/Re/S/1999/CPCSEA) and conducted under the provisions of the CPCSEA guidelines.

Consent for publication

Not applicable.

\section{Competing interests}

The authors declare that they have no competing interests.

\section{Author details}

${ }^{1}$ Sant Gajanan Maharaj College of Pharmacy Mahagaon, 416502, Tal-Gadhinglaj, Dist-Kolhapur, Maharashtra, India. ²Department of Pharmacognosy S.E.T.'s College of Pharmacy, Dharwad, Karnataka, India. ${ }^{3}$ Bharati Vidyapeeth College of Pharmacy, Kolhapur, Maharashtra, India.

Received: 29 April 2020 Accepted: 16 April 2021

Published online: 07 May 2021

\section{References}

1. Saleem TS, Chetty CM, Ramkanth S, Rajan VST, Kumar KM, Gauthaman K (2010) Hepatoprotective herbs: a review. Int J Res Pharm Sci 1(1):1-5

2. Pineiro-Carrero VM, Pineiro EO (2004) Liver. Pediatrics 113(4 Suppl):10971106

3. Subramoniam A, Pushpagadan P (1999) Development of phytomedicines for liver diseases. Indian J Pharmacol 31:166-175

4. Joyeux M, Rolland A, Fleurentin J, Mortier F, Dorfman P (1990) Tert--butyl hydro peroxide induced injury in isolated rat hepatocytes: a model for studying antihepatotoxic crude drugs. Planta Med 56:171-174

5. WHO, (1993) Regional Office For The Western Pacific, Research guidelines for evaluating the safety and efficacy of herbal medicines, Manila, WHO.

6. Malhotra S, (2001) Hepatotprotective natural products.2 (5): 110-111.

7. Qadry JS (2007) Pharmacognosy, B.S. Prakashan. Ahmedabad 08:156-195

8. Rawat AKS, Mehrotra S, Tripathi SC, Shome U (1997) Hepatoprotective activity of Boerhaavia diffusa L. roots a popular Indian ethnomedicine. J Ethnopharmacol 56:61-66 
9. Strobel G, Daisy B (2003) Bioprospecting for microbial endophytes and their natural products. Microbial Mol Biol Rev 67(4):491-502. https://doi.org/1 0.1128/MMBR.67.4.491-502.2003

10. Suthep W, Nongluksna S, Wattana P, Nuntawan T, Kannawat DK, Nijsiri R (2004) Endophytic fungi with anti microbial, anticancer and anti-malarial activities isolated from Thai medicinal plants. World J Microbiol Biotechnol 20:265-272

11. Geraldo HS, Helder LT, Henrique CT, Vanderlan S, Bolzani MCM (2005) New bioactive metabolites produced by Phomopsis cassiae, an endophytic fungus in Cassia spectabilis. J Braz Chem Soc 16(6):1463-1466

12. Karunai SB, Balagengatharathilagam P (2014) Isolation and screening of endophytic fungi from medicinal plants of Virudhunagar district for antimicrobial activity. Int J Sci Nat 5(1):147-155

13. Tejesvi MV, Kini KR, Prakash HS, Subbiah V, Shetty HS (2008) Antioxidant, antihypertensive and antibacterial properties of endophytic Pestalotiopsis species from medicinal plants. Can J Microbiol 54(9):769-780. https://doi. org/10.1139/W08-070

14. Hayashi T, Maruyama H, Kasai R, Hattori K, Takasuga S, Hazeki O (2002) Ellagitannins from Lagerstroemia speciosa as activators of glucose transport in fat cells. Planta Med 68(2):173-175. https://doi.org/10.1055/s-2002-20251

15. Oyaizu M (1986) Studies on product of browning reaction prepared from glucose amine. Japan J Nutr 44(6):307-315. https://doi.org/10.5264/eiyoga kuzashi.44.307

16. Narla RS, Rao MNA (1995) Scavenging of free radicals and inhibition of lipid peroxidation by 3-phenyl syndone. J Pharm Pharmacol 47(8):623-625. https://doi.org/10.1111/j.2042-7158.1995.tb05847.x

17. Ghosh MN (1984) Fundamentals of experimental pharmacology. 2ndEd. Calcutta: Scientific BookAgency 15:3-4

18. Qureshi AA, Prakash T, Patil T, Swamy VA, Gouda VA, Prabhu K, Setty SR (2007) Hepatoprotective and antioxidant activity of flowers of Calotriopisprocera (Ait) R.Br.in $\mathrm{CCl}_{4}$ induced hepatic damage. Ind J Exp Biol 45:304-310

19. Wolf PL, Williams D, Coplon N, Coulson AS (1972) Transaminase activities in serum of longtermhemodialysis patient. Clin Chem 18:567-568

20. Wilkinson JH, Winsten S (1969) Evaluation of new system for the kinetic measurement of serum alkaline phosphatase. Clin Chem 15:487

21. Pearlman PC, Lee RT (1974) Detection and measurement of total bilirubin in serum with use ofsurfactantsassolublizingagents. Clin Chem 20:447-449

22. Lowry OH, Rosenhrough NJ, Farr AL, Randall RJ (1951) Protein measurement with the Folin phenol reagent. J Biol Chem 193(1):265-275. https://doi.org/1 0.1016/S0021-9258(19)52451-6

23. Butinar L, Zalar P, Frisvad JC, Gunde-Cimerman N (2005) The genus Eurotium members of indigenous fungal community in hypersaline waters of salterns. FEMS Microbiology Ecology. 51(2):155-166. https://doi.org/10.101 6/j.femsec.2004.08.002

24. Brattin WJ, Glende EA Jr, Recknagel RO (1985) Pathological mechanisms in carbon tetrachloride hepatotoxicity. J Free Radic Biol Med 1(1):27-32. https://doi.org/10.1016/0748-5514(85)90026-1

25. Achliya GS, Kotgale SG, Wadodkar AK, Dorle AK (2003) Hepatoprotective activity of Panchgavya Gritha in carbon tetra chloride induced hepatotoxicity in rats. Ind J Pharmacol 35:311-315

26. Moss D, Butterworth PJ (1974) In Enzymology and medicine. Pitman Medical, London, vol 1, p 139

27. Taju G, Jayanthia S, Majeed A (2011) Evaluation of hepatoprotective and antioxidant activity of Psidiumguayava extract against acetaminophen induced liver injury in rats. Int J Toxicol App Pharm 1:13-20

28. Monira A, Naima ZM (2012) Evaluation of protective and anioxidant activity of Thyme (Thumus vulgaris) extract on paracetamol-induced toxicity in rats. Aust J Basic Appl Sci. 6:467-474

29. Das S, Sarma G (2009) Study of hepatoprotective activity of ethanolic extract of the pulp of Eugina jambolana (JAMUN) in albino rats. J Clin Diagn Res. 3:1466-1474

30. Ottu OJ, Atawodi SE, Onyike E (2013) Antioxidant, hepatoprotective and hypolipidemic effetcs of methanolic root extract of Cassia singueana in rats following acute and chronic carbon tetrachloride intoxication. Asian Pac J Trop Med 1:609-615

31. Ojo OO, Kabutu FR, Bello M, Babayo U (2006) Inhibition of paracetamolinduced oxidative stress in rats by extracts of lemongrass (Cymbropogon citrates) and green tea (Camellia sinensis) in rats. Afr J Biotechnol 5:12271232
32. Effiong GS, Udoh IE, Udo NM, Asuquo EN, Wilson LA, Ntukidem IU, Nwoke IB (2013) Assessment of hepatoprotective and antioxidant activity of Nauclea latifolia leaf extract against acetaminophen induced hepatotoxicity in rats. Int Res J Plant Sci 4:55-63

33. Amol NM, Pradeeo BP, Kishori GP (2013) Evaluation of activity of whole stem extracts of Oroxylum Indicum on paracetamol-induced hepatotoxicity. Int J Phama Biol Sci 4:255-265

\section{Publisher's Note}

Springer Nature remains neutral with regard to jurisdictional claims in published maps and institutional affiliations.

\section{Submit your manuscript to a SpringerOpen ${ }^{\circ}$ journal and benefit from:}

- Convenient online submission

- Rigorous peer review

- Open access: articles freely available online

- High visibility within the field

- Retaining the copyright to your article

Submit your next manuscript at $\boldsymbol{\nabla}$ springeropen.com 